\title{
Use of Group 4 Bis(sulfonamido) Complexes in the Intramolecular Hydroamination of Alkynes and Allenes
}

\author{
Lutz Ackermann†, Robert G. Bergman*, and Rebecca N. Loy \\ Contribution from the Department of Chemistry and Center for New Directions in Organic Synthesis, \\ University of California, Berkeley, California 94720-1460
}

\begin{abstract}
Titanium tetrakis(amido) complexes catalyze the intramolecular hydroamination of alkynes and allenes more efficiently than Cp-based species. We report here that electron-withdrawing and sterically demanding bis(sulfonamido) ligands lead to enhanced catalytic activity. Zirconium analogues have also been prepared, and the tosyl-substituted complex $\mathbf{2 0}$ has been structurally characterized. As in the titanium series, bis(sulfonamido) zirconium catalysts are more efficient in the intramolecular hydroamination of allenes than bis(cyclopentadienyl) complex $\mathrm{Cp}_{2} \mathrm{ZrMe}_{2}$ (23). Furthermore, these compounds transform 1,3-disubstituted aminoallenes with high stereoselectivity to the $Z$-allylamines and allow the hydroamination of a trisubstituted allene. Titanium bis (sulfonamido) imido complex $\mathbf{2 7}$ was synthesized. It converts aminoallene 10 to cylic imine $\mathbf{1 1}$ with a rate comparable to that of tetrakis(amide) $\mathbf{1 5}$, supporting the hypothesis of a catalytically active titanium imido intermediate.
\end{abstract}

\section{Introduction}

The direct addition of a $\mathrm{N}-\mathrm{H}$ bond across a carbon-carbon multiple bond, the hydroamination reaction, constitutes an atom-economical method for the synthesis of substituted amines. 1,2 While a general procedure for the hydroamination of unactivated alkenes remains elusive, ${ }^{3}$, 4 appreciable progress has been made in developing analogous transformations of alkynes. 5 ,

6 The first catalytic intermolecular hydroamination of alkynes used highly toxic mercury and thallium compounds. ${ }^{7,8}$ More recently, reactions relying on alkali metal bases, ${ }^{9}$ organolanthanides 10,11 and -actinides 12 as well as late transition metals, such as palladium, 13 rhodium, ${ }^{14}$ and ruthenium, ${ }^{15,16}$ have been developed. However, the extreme air- and water-sensitivity of the former and the high costs of the latter compounds are significant drawbacks to these procedures.

In contrast to many other potential catalysts, titanium and zirconium complexes are readily available and inexpensive. In the early 1990s, we reported the catalytic activity of zirconocene amido complexes in the hydroamination of alkynes. ${ }^{17,18}$ Subsequently, Doye disclosed the intermolecular hydroamination of alkynes using $\mathrm{Cp}_{2} \mathrm{TiMe}_{2}{ }^{19}$ (1) as the precatalyst. ${ }^{20-24}$ Detailed mechanistic investigations of this reaction in our group revealed that the catalytically active species is generated via an unexpected $\mathrm{Cp} /$ amido ligand exchange. ${ }^{25,26}$ The isolated monocyclopentadienyl titanium amido complex $\mathrm{Cp}(\mathrm{ArNH})(\mathrm{py}) \mathrm{Ti}=\mathrm{NAr}(\mathrm{Ar}=2,6-$ $\left.(\mathrm{Me})_{2} \mathrm{C}_{6} \mathrm{H}_{3}\right)(2)^{27}$ exhibits enhanced catalytic activity in the hydroamination of alkynes and allenes. ${ }^{25}$ Therefore, we wondered if the efficiency could be further increased by the

E-mail: bergman@cchem.berkeley.edu.

Present address: Department of Chemistry, Ludwig-Maximilians-Universitaet, D-81377 Muenchen, Germany.

Supporting Information Available: Experimental procedures and characterization data for new compounds (PDF). This material is available free of charge via the Internet at http://pubs.acs.org. 
replacement of the remaining Cp ligand in $\mathbf{2}$ by another amide. ${ }^{28}$ A report from Odom's group ${ }^{29}$ revealed that hydroamination reactions can be mediated by commercially available $\mathrm{Ti}\left(\mathrm{NMe}_{2}\right)_{4}(\mathbf{3})$ and, hence, confirmed our hypothesis. On the basis of these results, Odom and co-workers developed efficient titanium dipyrrolylmethane catalysts for the hydroamination of alkynes. ${ }^{30-33} \mathrm{We}$, however, were intrigued by the potential of using titanium bis (sulfonamido) complexes ${ }^{34}$ to accomplish regioselective hydroamination reactions. Herein, we (a) disclose a comprehensive investigation of titanium- and zirconium-catalyzed intramolecular hydroamination reactions of alkynes and allenes, (b) show that the reactivity and regioselectivity of these cyclization reactions strongly depend on the transition metal as well as the ligand set, and (c) provide evidence for a titanium imido intermediate in the catalytic cycle.

\section{Results and Discussion}

\section{Hydroamination of Alkynes.}

At the outset of our studies, we evaluated the catalytic activity of various titanium complexes in the intramolecular hydroamination of alkyne 4 to cyclic imine 5 (eq 1).

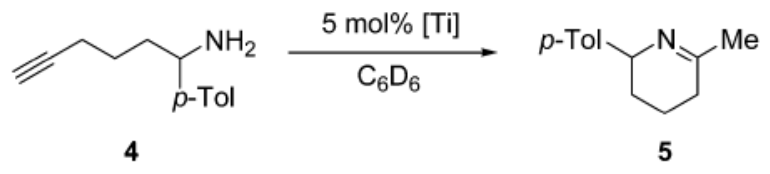

(1).

Titanium tetrakis(alkoxide) complexes, such as TADDOL-compound $\mathbf{6}^{35}$ or salen-complex $7^{36}$ (Figure 1), afforded no product even at elevated temperature (Table 1, entries 1 and 2). Replacing two alkoxides with dimethylamides, as in BINOL-or TADDOL-complexes 8 and 9, gave rise to catalytic activity, but the conversion was rather slow even at $75^{\circ} \mathrm{C}$ (entries 3 and 4). ${ }^{37,38}$ Commercially available $\mathrm{Ti}\left(\mathrm{NMe}_{2}\right)_{4}(\mathbf{3})$ efficiently converted aminoalkyne 4 to imine 5 even at room temperature (entry 5).

\section{Hydroamination of Allenes.}

Since the hydroamination of alkynes is easily effected by titanium tetrakis(amide) $\mathbf{3},{ }^{28,37}$ these substrates are of limited value for probing the reactivity of potentially more powerful catalysts. The hydroamination of allenes, however, is more challenging 25 and hence constitutes a more stringent assay of catalytic activity. Additionally, the hydroamination of aminoallenes can result in two different regioisomers (Scheme 1). Whereas Ag-, $\mathrm{Hg}-$, and $\mathrm{Pd}-$ based precatalysts exclusively provide allylamines via pathway a, ${ }^{39-43}$ lanthanide complexes convert monosubstituted aminoallenes into mixtures of the two regioisomers (pathways a and $b$ ). However, it is noteworthy that lanthanide catalysts convert 1,3-disubstituted aminoallenes exclusively to the corresponding allylamine. ${ }^{44-46}$

We studied the conversion of aminoallene $\mathbf{1 0}$ using $5 \mathrm{~mol} \%$ of various titanium catalyst precursors (eq 2). The Cp-based complexes $\mathrm{Cp}_{2} \mathrm{TiMe}_{2}$ (1) and CpTi(NHAr)(NAr)py (Ar: 2,6dimethylphenyl) (2) have been applied successfully in numerous intermolecular hydroamination reactions of allenes. ${ }^{25}$ Unexpectedly, the intramolecular transformation proceeded relatively slowly at $75{ }^{\circ} \mathrm{C}$, and harsher reaction conditions were necessary to guarantee a quantitative conversion of substrate $\mathbf{1 0}$ (Table 2, entries 1 and 2). On the other hand, tetrakis(amide) $\mathbf{3}$ accomplishes the formation of imine $\mathbf{1 1}$ selectively at room temperature, although a temperature of $75^{\circ} \mathrm{C}$ is necessary to achieve a practical reaction rate (entry 3). Since titanium bis-(sulfonamides) such as $\mathbf{1 3}$ are readily available following Walsh's procedure, ${ }^{34}$ we also explored the use of tosyl-substituted complex $\mathbf{1 3}$ in the hydroamination 
of aminoallene 10. The chelating bis(sulfonamido) ligand resulted in a significantly increased reactivity, leading to selective and quantitative product formation even at room temperature (entry 4). The chelating $N, N^{\prime}$-dimethyl-substituted complex 14, however, exhibits a reactivity profile similar to that of $\mathrm{Ti}\left(\mathrm{NMe}_{2}\right)_{4}(3)$ (entry 5). Therefore, the bidentate nature of the ligand is not the sole source of enhanced reactivity. The improved performance of $\mathbf{1 3}$ might instead be a consequence of a weak coordination of the sulfur-bound oxygen atoms to the metal center $^{34}$ or of the different electronic properties of the bis-(sulfonamido) ligand (vide infra). Furthermore, the six-membered ring product is formed exclusively using titanium tetrakis (amide) complexes.
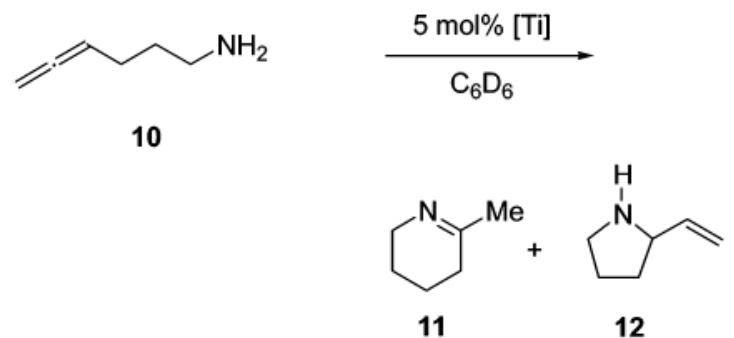

(2).

Having discovered the increased reactivity as well as the improved regioselectivity of bis (sulfonamide)-based catalyst $\mathbf{1 3}$, we studied the substrate scope provided by $\mathbf{1 3}$ in intramolecular hydroamination reactions of allenes. Differently substituted aminoallenes were synthesized following the general sequence depicted in Scheme 2.

When the $\alpha$-position of a monosubstituted aminoallene bore an aromatic group, the regioselectivity of the cyclization depended upon the nature of the amido ligands (Table 3). While 3 generated a mixture of regioisomers (5-10\% allylamine), the chelated titanium complex 13 formed the cyclic imines as the sole products, thereby allowing the isolation of these compounds by simple filtration through $\mathrm{K}_{2} \mathrm{CO}_{3}$. The examples listed in Table 3 demonstrate the superior activity of $\mathbf{1 3}$, which led to completion at significantly reduced reaction times. This system tolerates a range of substituents on the aromatic ring and provides the respective products in good yields, thus offering the possibility for further transformations (entries 5-8). More important, the scope of this procedure is not limited to the generation of relatively strain-free six-membered rings, but can also be extended to the formation of sevenmembered ring systems (entry 9). ${ }^{47}$

\section{Steric Influence of the Bis(sulfonamido) Ligand.}

The influence of steric congestion around the metal center of the bis(sulfonamido) catalyst was studied by comparing the reactivity of $p$-tolyl-substituted precursor $\mathbf{1 3}$ with that of mesitylsubstituted complex $\mathbf{1 5}^{\mathbf{3}}$ (Figure 2). Both precatalysts efficiently convert aminoalkynes and monosubstituted aminoallenes regioselectively to six-membered cyclic imines (Table 4, entries $1-4)$. They are also capable of affecting the more demanding hydroamination of 1,3disubstituted allenes, ${ }^{48}$ yielding exclusively the corresponding cyclic imines (entries 5-8). The data obtained thus far suggest that the efficacy of the sterically more hindered catalyst $\mathbf{1 5}$ exceeds that of tosyl-substituted complex 13 (entry 1 versus 2 and 5 versus 6).

\section{Electronic Influence of the Bis(sulfonamido) Ligand.}

To study the influence of the electronic nature of the bis-(sulfonamido) ligand on the catalytic activity, we synthesized the methyl- and trifluoromethyl-substituted analogues $\mathbf{1 6}$ and $\mathbf{1 7}$ from $\mathrm{Ti}\left(\mathrm{NMe}_{2}\right)_{4}$ (3) and the corresponding bis(amide) (eq 3). 


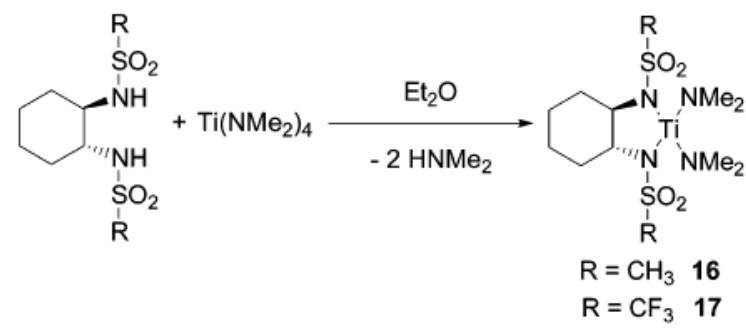

(3).

While bis(triflamide) $\mathbf{1 7}$ converted aminoalkyne $\mathbf{4}$ to imine $\mathbf{5}$ selectively and efficiently even at room temperature ( $47 \%$ conversion after $15 \mathrm{~min}$ ), no transformation of 4 was achieved by the methyl-substituted complex 16 at this temperature (90 $\mathrm{min},{ }^{1} \mathrm{H}$ NMR). These experiments illustrate the importance of the electron-withdrawing nature of the sulfonamido ligands on the catalytic activity. Furthermore, bis(triflamido) complex 17 converts aminoallenes selectively to the corresponding cyclic imines (Table 5). The transformation of 1,3-disubstituted allene 18 demonstrates the increased efficacy of bis(triflamide) 17, yielding $87 \%$ of imine 19 at $75^{\circ}$ $\mathrm{C}$ after $20 \mathrm{~h}$. Note that complex $\mathbf{1 3}$ affords only $12 \%$ of $\mathbf{1 9}$ under the same reaction conditions.

\section{Zirconium Analogues.}

Previously we have carried out nitrogen-carbon bond-forming reactions using zirconium imido complexes. $17,18,49$ Therefore, we were interested in comparing the synthesis and catalytic activity of titanium complexes $\mathbf{1 3}$ and $\mathbf{1 5}$ with their zirconium analogues. The corresponding tosyl-and mesitylsulfonyl-substituted complexes $\mathbf{2 0}$ and $\mathbf{2 1}$ (Figure 3) were obtained starting from $\mathrm{Zr}\left(\mathrm{NMe}_{2}\right)_{4}(\mathbf{2 2})$ as outlined for the respective titanium complexes.

Whereas mesitylsulfonyl complex 21 showed the expected NMR features, tosyl-substituted compound 20 exhibited resonances for two separate sets of $p$-tolyl groups. In addition, 1 equiv of $\mathrm{HNMe}_{2}$ was detected. A crystal structure analysis was performed and unambiguously confirmed the structure of $\mathbf{2 0}$ shown in Figure 4. This confirms that coordination of the sulfurbound oxygen atoms to the metal center has occurred.

Initially, we explored the catalytic reactivity of a variety of different zirconium species in the hydroamination of parent aminoallene $\mathbf{1 0}$ (eq 2). The cyclopentadienyl-based complex $\mathbf{2 3}$ converted the aminoallene to products $\mathbf{1 1}$ and $\mathbf{1 2}$ slowly even at a temperature of $135^{\circ} \mathrm{C}$ (Table 6 , entry 1). Abstraction of a methyl group with $\mathrm{B}\left(\mathrm{C}_{6} \mathrm{~F}_{5}\right)_{3}$ prior to the addition of the substrate led to an acceleration of the reaction at $135^{\circ} \mathrm{C}$. The cationic zirconium complex gave an inverted regioselectivity, yielding the allylamine as the major product (entry 2). In analogy to the titanium series, a more pronounced effect was observed upon switching from a $\mathrm{Cp}$ to an amido ligand set, illustrated by a lower reaction temperature of $75{ }^{\circ} \mathrm{C}$ (entry 3 ). The reaction was even faster using bis(sulfonamido) complexes (entries 4 and 5). While the tosyl-substituted sulfonamide complex 20 exhibited a catalytic activity comparable to that of $\mathrm{Zr}\left(\mathrm{NMe}_{2}\right)_{4}(\mathbf{2 2})$ (entry 4), mesitylsulfonyl-substituted compound $\mathbf{2 1}$ was a precursor to a significantly more efficient catalyst (entry 5). This improved performance can be rationalized by the increased steric hindrance around the metal center, as observed in the titanium series. In contrast to the analogous titanium species, the use of zirconium complexes yields significant amounts of allylamine 12. The introduction of substituents at the terminal position of the allene moiety inverts the regioselectivity of the cyclization reaction (eq 4). Several examples demonstrate that the regioselectivity changes from 1:16 (Table 6, entry 5) for the parent substrate to 4:1 and 7:1 (Table 7, entries 1 and 2) in the case of 1,3-disubstituted aminoallenes. Furthermore, the diastereoselectivity is excellent for the conversion of 1,3-disubstituted substrates, yielding the corresponding $Z$-isomers $\mathbf{2 4}$ and $\mathbf{2 5}$ exclusively. The scope of this transformation is further 
highlighted by the hydroamination of a trisubstituted allene (Table 7, entry 3 ). In this case, a good regioselectivity of 11:1 favoring allylamine $\mathbf{2 6}$ is obtained.

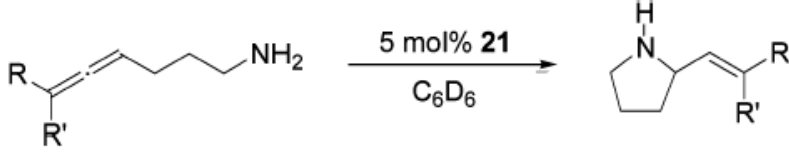

(4).

\section{Mechanistic Considerations.}

The mechanism of the $\mathrm{Cp}_{2}-\mathrm{TiMe}_{2}$-catalyzed hydroamination reaction has been investigated experimentally 25,50 and theoretically. ${ }^{26}$ These studies suggest that the catalytically active species is a titanium imido complex. To gain insight into the mechanism of the reaction mediated by tetrakis(amido) precursors, we performed the stoichiometric reaction between titanium catalyst $\mathbf{1 5}$ and a primary amine (eq 5). To avoid a potential dimerization of the imido species, ${ }^{25,26}$ we chose the sterically hindered 2,6-dimethylaniline. Monitoring the reaction by ${ }^{1} \mathrm{H}$ NMR revealed the formation of imido complex 27 accompanied by liberation of $\mathrm{HNMe}_{2}$. Pyridine was added to stabilize the imido compound, and the resulting adduct was isolated in $61 \%$ yield, contaminated with free amine. All attempts to remove the remaining impurities met with no success, which prevented satisfactory elemental analysis. Difficulties associated with removing amine contaminants from early transition metal imido species have been reported previously. $25,51,52$ Imido complex 27 (5 mol \%) converts aminoallene 10 quantitatively to imine $\mathbf{1 1}$ after $3 \mathrm{~h}$ at room temperature and, hence, leads to a reaction with a rate comparable to that observed using precatalyst $\mathbf{1 5}$.

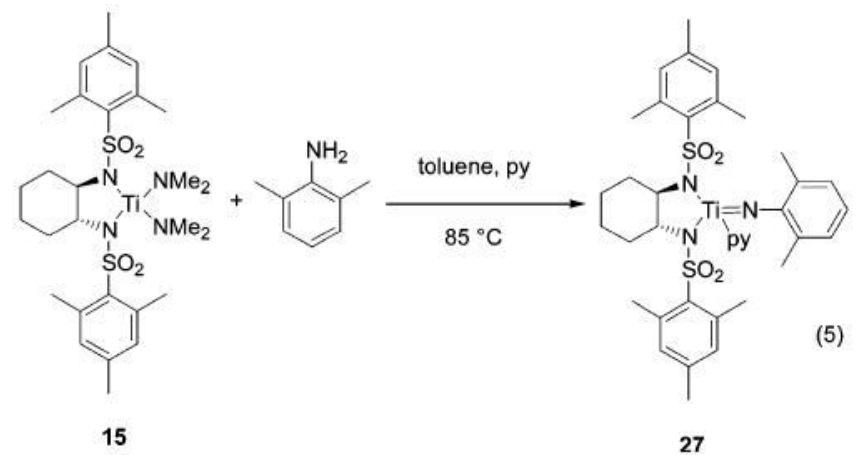

(5).

Knochel and co-workers have shown that intramolecular hydroamination reactions of alkynes can be mediated by bases. ${ }^{9,53,54}$ However, catalytic amounts of $\mathrm{LiNMe}_{2}(10 \mathrm{~mol} \%)$ isomerized aminoallene $\mathbf{1 0}$ quantitatively in $1 \mathrm{~h}$ at ambient temperature to internal alkyne $\mathbf{2 8}$ (observed by ${ }^{1} \mathrm{H}$ and ${ }^{13} \mathrm{C}$ NMR). Alkyne 28 was subsequently converted to the five-membered cyclization product $\mathbf{2 9}$ (eq 6). Imine $\mathbf{2 9}$ was observed neither in the titanium- nor in the zirconium-catalyzed reactions. Therefore, it seems unlikely that the catalytic activity originates from traces of free amide. 


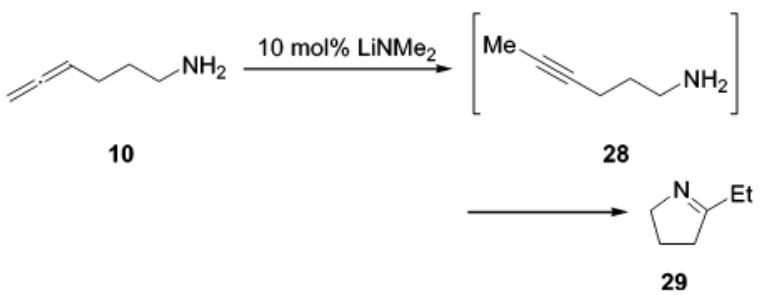

(6).

On the basis of our results, we propose the catalytic cycle depicted in Scheme 3 for the hydroamination reactions discussed in this work (illustrated for titanium and an allene). In the crucial steps of this mechanism, a formal [2+2] cycloaddition of the imido species with the allene is followed by a stepwise protonation of the azametallacyclobutane to regenerate the actual catalysts as well as to release the hydroamination product.

\section{Conclusion}

Titanium tetrakis(amido) complexes catalyze the intramolecular hydroamination of alkynes and allenes more efficiently than do $\mathrm{Cp}$-based species. The catalytic activity can be increased through the use of electron-withdrawing or sterically demanding bis(sulfonamido) ligands. Analogous zirconium complexes have been synthesized, and one of them has been structurally characterized. These complexes catalyze the intramolecular hydroamination of allenes more efficiently than $\mathrm{Cp}_{2} \mathrm{ZrMe}_{2}$ (23). More importantly, these compounds convert 1,3-disubstituted aminoallenes with good stereoselectivity to the $Z$-allylamines and allow the hydroamination of a trisubstituted allene moiety. Finally, titanium bis(sulfonamido) imido complex 27 cyclizes aminoallene $\mathbf{1 0}$ at a rate comparable to that observed using tetrakis(amide) $\mathbf{1 5}$, supporting the hypothesis that in the catalytic cycle a titanium imido species is an important intermediate.

\section{Experimental Section}

\section{General.}

All syntheses were carried out under $\mathrm{N}_{2}$ using predried glassware. All hydroamination reactions and complex synthesis were performed in a $\mathrm{N}_{2}$-filled Vacuum Atmospheres inert atmosphere box. $\mathrm{Et}_{2} \mathrm{O}$, pyridine, THF, and $d_{6}$-benzene were dried by distillation over $\mathrm{Na}$ and transferred under $\mathrm{N}_{2} \cdot \mathrm{CH}_{2} \mathrm{Cl}_{2}$, benzene, $n$-pentane, and toluene were dried by passing through a single column of activated alumina. ${ }^{55,56}$ Flash chromatography: Merck silica gel 60 (230400 mesh). NMR:

Spectra were recorded on Bruker AMX300 or AMX400 spectrometers in the solvents indicated; chemical shifts $(\delta)$ are given in ppm relative to TMS, coupling constants $(J)$ in $\mathrm{Hz}$. 1,3,5-Trimethoxybenzene (Aldrich) was employed as an internal standard in NMR tube reactions. IR: Mattson Galaxy FTIR 3000, wavenumbers in $\mathrm{cm}^{-1}$; only selected data are reported. Mass spectra were performed by the University of California, Berkeley Micro-Mass Facility.

Herein, selected representative procedures are reported. A fully detailed account is provided in the Supporting Information.

\section{General Procedure for the Synthesis of Titanium and Zirconium Complexes. 57}

Under an $\mathrm{N}_{2}$ atmosphere, the appropriate ligand (1 mmol) was stirred in $\mathrm{Et}_{2} \mathrm{O}(10 \mathrm{~mL})$ at room temperature. To this mixture was added $\mathrm{Ti}\left(\mathrm{NMe}_{2}\right)_{4}(1 \mathrm{mmol})$ as a solution in $\mathrm{Et}_{2} \mathrm{O}(1 \mathrm{~mL})$ in one portion. On addition of the titanium complex, the mixture turned red-brown, and the ligand dissolved to give a clear solution. If necessary, the solution was filtered after the ligand had 
dissolved. When no undissolved ligand remained, stirring was discontinued and the solution was cooled to $-35^{\circ} \mathrm{C}$. The solution was decanted, washed with cold $\mathrm{Et}_{2} \mathrm{O}\left(1 \mathrm{~mL},-35^{\circ} \mathrm{C}\right)$, and the product was dried in vacuo.

Following the general procedure, $\mathbf{2 0}$ was obtained as white crystals in $46 \%$ yield.

${ }^{1} \mathrm{H}$ NMR $\left(\mathrm{C}_{6} \mathrm{D}_{6}, 400 \mathrm{MHz}\right): \delta 8.03(2 \mathrm{H}, \mathrm{d}, J=8.2 \mathrm{~Hz}), 7.96(2 \mathrm{H}, \mathrm{d}, J=8.2 \mathrm{~Hz}), 6.87(2 \mathrm{H}, \mathrm{d}$, $J=7.9 \mathrm{~Hz}), 6.81(2 \mathrm{H}, \mathrm{d}, J=8.1 \mathrm{~Hz}), 3.45-3.35(2 \mathrm{H}, \mathrm{m}), 3.41(6 \mathrm{H}, \mathrm{s}), 3.23(6 \mathrm{H}, \mathrm{s}), 2.40(6 \mathrm{H}$, $\mathrm{d}, J=6.1 \mathrm{~Hz}), 2.20(1 \mathrm{H}, \mathrm{m}), 1.99(1 \mathrm{H}, \mathrm{m}), 1.88(3 \mathrm{H}, \mathrm{s}), 1.87(3 \mathrm{H}, \mathrm{s}), 1.70(1 \mathrm{H}, \mathrm{m}), 1.34(1 \mathrm{H}$, m), $1.26(1 \mathrm{H}, \mathrm{m}), 1.20-0.85(3 \mathrm{H}, \mathrm{m}) .{ }^{13} \mathrm{C}$ NMR $\left(\mathrm{C}_{6} \mathrm{D}_{6}, 100 \mathrm{MHz}\right): \delta 142.7,142.4,129.8$, 129.5, 128.1, 127.9, 126.8, 126.1, 65.2, 63.7, 47.6, 44.6, 42.8, 40.3, 32.8, 24.7, 21.1, 21.1. IR $\left(\mathrm{CH}_{2} \mathrm{Cl}_{2}\right): 3363,3284,3065,3054,2938,2859,1599,1451,1428,1337,1262,1162,1093$, $904 \mathrm{~cm}^{-1} . \mathrm{C}_{26} \mathrm{H}_{43} \mathrm{~N}_{5} \mathrm{O}_{4} \mathrm{~S} \mathrm{~S}_{2} \mathrm{Zr}$ (645.01) Anal. Calcd: C, 48.42; H, 6.72; N, 10.86. Found: C, 48.36; H, 6.66; N, 10.51 .

\section{Typical Procedure for the Hydroamination/Cyclization Reaction.}

A solution of 1-(4-fluoro-phenyl)-hexa-4,5-dienyl-1-amine (121 mg, $0.63 \mathrm{mmol})$ and $\mathbf{1 3}$ (18 $\mathrm{mg}, 0.03 \mathrm{mmol})$ in benzene $(3 \mathrm{~mL})$ was heated for $10 \mathrm{~h}$ to $75^{\circ} \mathrm{C}$. The solution was cooled and treated with 20 drops of methanolic $\mathrm{NaOH}(10 \%)$. The mixture was stirred for $0.5 \mathrm{~h}$ at room temperature and concentrated in vacuo. The remaining residue was extracted with $n$-hexane $(30 \mathrm{~mL})$ and filtered through $\mathrm{K}_{2} \mathrm{CO}_{3}$ to afford 2-(4-fluoro-phenyl)-6-methyl-2,3,4,5tetrahydro-pyridine $(112 \mathrm{mg}, 93 \%)$ as a pale yellow oil with a purity of $>95 \%$ by NMR.

\section{2-(4-Fluoro-phenyl)-6-methyl-2,3,4,5-tetrahydro-pyridine.}

${ }^{1} \mathrm{H}$ NMR $\left(\mathrm{CD}_{2} \mathrm{Cl}_{2}, 300 \mathrm{MHz}\right): \delta 7.23(\mathrm{~m}, 2 \mathrm{H}), 7.01(\mathrm{tm}, 2 \mathrm{H}, J=8.9 \mathrm{~Hz}), 4.43(\mathrm{~m}, 1 \mathrm{H}), 2.30$ $2.10(\mathrm{~m}, 2 \mathrm{H}), 1.98(\mathrm{~d}, 3 \mathrm{H}, J=2.0 \mathrm{~Hz}), 1.95-1.60(\mathrm{~m}, 3 \mathrm{H}), 1.40-1.20(\mathrm{~m}, 1 \mathrm{H}) .{ }^{13} \mathrm{C}$ NMR $\left(\mathrm{CD}_{2} \mathrm{Cl}_{2}, 100 \mathrm{MHz}\right): \delta$ 168.6, 128.4, 128.3, 114.8, 114.5, 60.8, 30.6, 29.9, 27.3, 19.0. MS (EI) $\mathrm{m} / \mathrm{z}$ (relative intensity): 191 (81) [ $\left.\mathrm{M}^{+}\right], 163$ (14), 162 (14), 148 (11), 121 (100), 109 (10). HRMS (EI) $m / z$ : calcd for $\mathrm{C}_{12} \mathrm{H}_{14} \mathrm{FN}, 191.1110$; found, 191.1109.

\section{Acknowledgements}

This work was supported by the U.S. National Institutes of Health (Grant No. GM-25459 to R.G.B.). L.A. thanks the Deutscher Akademischer Austauschdienst (DAAD) for a postdoctoral fellowship. The structural study of 20 was carried out by Drs. A. G. Oliver and F. J. Hollander of the U. C. Berkeley College of Chemistry X-ray Diffraction Facility (CHEXRAY). The Center for New Directions in Organic Synthesis is supported by Bristol-Myers Squibb as a sponsoring member and Novartis as a supporting member.

\section{References}

1. Müller TE, Beller M. Chem Rev 1998;98:675. [PubMed: 11848912]

2. Nobis M, Driessen-Hölscher B. Angew Chem, Int Ed 2001;40:3983.

3. As early as 1993, the catalytic anti-Markovnikov addition of amines to olefins was mentioned as one of the top 10 challenges for catalysis: HagginJChem Eng News1993716

4. For leading references for the hydroamination of activated alkenes, see: (a) CasalnuovoALCalabreseJCMilsteinDJ Am Chem Soc19881106738 b Dorta R, Egli P, Zürchner F, Togni A. J Am Chem Soc 1997;119:10857. c Beller M, Eichberger M, Trauthwein H. Angew Chem, Int Ed Engl 1997;36:2225. d Kawatsura M, Hartwig JF. J Am Chem Soc 2000;122:9546. e Kawatsura M, Hartwig JF. Organometallics 2001;20:1960. f Fadini L, Togni A. Chem Commun 2003:30.

5. Shimada T, Yamamoto Y. J Am Chem Soc 2002;124:12670. [PubMed: 12392408]

6. For a review, see: PohlkiFDoyeSChem Soc Rev200332104 [PubMed: 12683107]

7. Barluenga J, Aznar F. Synthesis 1977:195.

8. Barluenga J, Aznar F, Liz R, Rodes R. J Chem Soc, Perkin Trans 1 1980:2732.

9. Seayad J, Tillack A, Hartung CG, Beller M. Adv Synth Catal 2002;344:795. 
10. Li Y, Marks TJ. Organometallics 1996;15:3770.

11. Li Y, Marks TJ. J Am Chem Soc 1998;120:1757.

12. Haskel A, Straub T, Eisen MS. Organometallics 1996;15:3773.

13. Yamamoto Y, Radhakrishnan U. Chem Soc Rev 1999;28:199.

14. Hartung CG, Tillack A, Trautwein H, Beller M. J Org Chem 2001;66:6339. [PubMed: 11559184]

15. Uchimaru Y. Chem Commun 1999:1133.

16. Tokunaga M, Eckert M, Wakatsuki Y. Angew Chem, Int Ed 1999;38:3222.

17. Baranger AM, Walsh PJ, Bergman RG. J Am Chem Soc 1993;115:2753.

18. Walsh PJ, Baranger AM, Bergman RG. J Am Chem Soc 1992;114:1708.

19. Siebenreicher H, Doye S. J Prakt Chem 2000;342:102.

20. Haak E, Bytschkov I, Doye S. Angew Chem, Int Ed 1999;38:3389.

21. Bytschkov I, Doye S. Eur J Org Chem 2001:4411.

22. Pohlki F, Heutling A, Bytschkov I, Hotopp T, Doye S. Synlett 2002:799.

23. Siebenreicher H, Doye S. Eur J Org Chem 2002:1213.

24. For titanium-based hydroamination catalysts, see also: (a)

TillackACastroIGHartungCGBellerMAngew Chem, Int Ed2002412541 b Ong TG, Yap GPA, Richeson DS. Organometallics 2002;21:2839.

25. Johnson JS, Bergman RG. J Am Chem Soc 2001;123:2923. [PubMed: 11456996]

26. Straub BF, Bergman RG. Angew Chem, Int Ed 2001;40:4632.

27. McGrane PL, Livinghouse T. J Org Chem 1992;57:1323.

28. Ackermann L, Bergman RG. Org Lett 2002;4:1475. [PubMed: 11975607]

29. Shi Y, Ciszewski JT, Odom AL. Organometallics 2001;20:3967.

30. Shi Y, Hall C, Ciszewski JT, Cao C, Odom AL. Chem Commun 2003:586.

31. Harris SA, Ciszewski JT, Odom AL. Inorg Chem 2001;40:1987. [PubMed: 11304138]

32. Li Y, Turnas A, Ciszewski JT, Odom AL. Inorg Chem 2002;41:6298. [PubMed: 12444773]

33. Cao C, Ciszewski JT, Odom AL. Organometallics 2001;20:5011.

34. Pritchett S, Gantzel P, Walsh PJ. Organometallics 1999;18:823.

35. Seebach D, Plattner DA, Beck AK, Wang YM, Hunziker D, Petter W. Helv Chim Acta 1992;75:2171.

36. Flores-Lopéz LZ, Parra-Hake M, Somanathan R, Walsh PJ. Organometallics 2000;19:2153.

37. Duncan D, Livinghouse T. Organometallics 1999;18:4421.

38. For the catalytic activity of isolated alkoxo(imido) titanium complexes, see:

HillJEProfiletRDFanwickPERothwellIPAngew Chem Int Ed Engl199029664

39. Arseniyadis S, Gore J. Tetrahedron Lett 1983;24:3997.

40. Kinsman R, Lathbury D, Vernon P, Gallagher T. J Chem Soc, Chem Commun 1987:243.

41. Fox DNA, Gallagher T. Tetrahedron 1990;46:4697.

42. Al-Masum M, Meguro M, Yamamoto Y. Tetrahedron Lett 1997;38:6071.

43. Meguro M, Yamamoto Y. Tetrahedron Lett 1998;39:5421.

44. Arredondo VM, McDonald FE, Marks TJ. J Am Chem Soc 1998;120:4871.

45. Arredondo VM, Tian S, McDonald FE, Marks TJ. J Am Chem Soc 1999;121:3633.

46. Arredondo VM, McDonald FE, Marks TJ. Organometallics 1999;18:1949.

47. Note that the synthesis of seven-membered rings was not achieved using $\mathrm{Cp}_{2} \mathrm{TiMe}_{2}$ :

BytschkovIDoyeSTetrahedron Lett2002433715

48. All attempts to convert acyclic disubstituted allenes using cyclopentadienyl-based titanium catalysts have met with no success. ${ }^{25}$

49. Sweeney ZK, Salsman JL, Andersen RA, Bergman RG. Angew Chem, Int Ed 2000;39:2339.

50. Pohlki F, Doye S. Angew Chem, Int Ed 2001;40:2305.

51. Arney DJ, Bruck MA, Huber SR, Wigley DE. Inorg Chem 1992;31:3749.

52. Blake AJ, Collier PE, Dunn SC, Li WS, Mountford P, Shishkin OV. J Chem Soc, Dalton Trans 1997:1549.

53. Koradin C, Dohle W, Rodriguez AL, Schmid B, Knochel P. Tetrahedron 2003;59:1571. 
54. Rodriguez AL, Koradin C, Dohle W, Knochel P. Angew Chem, Int Ed 2000;39:2488.

55. Alaimo PJ, Peters DW, Arnold J, Bergman RG. J Chem Educ 2001;78:64.

56. Pangborn AB, Giardello MA, Grubbs RH, Rosen RK, Timmers FJ. Organometallics 1996;15:1518.

57. A general procedure for the synthesis of such titanium complexes has been reported. ${ }^{34}$ 


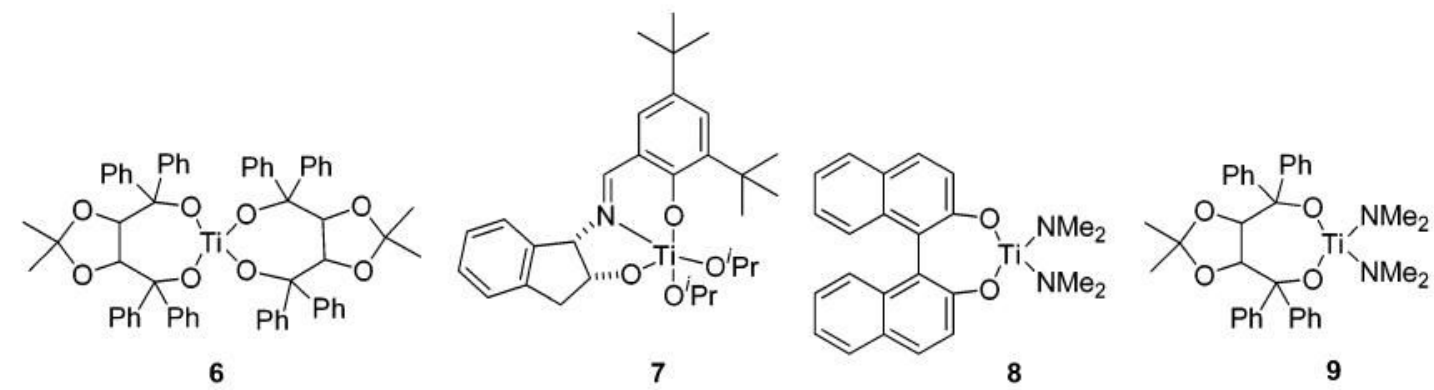

Figure 1.

Titanium alkoxo complexes. 


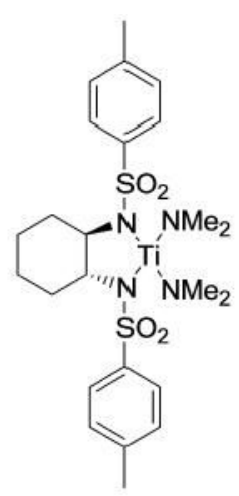

13

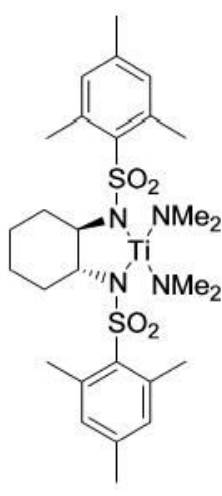

15

Figure 2.

Titanium bis(sulfonamido) complexes. 

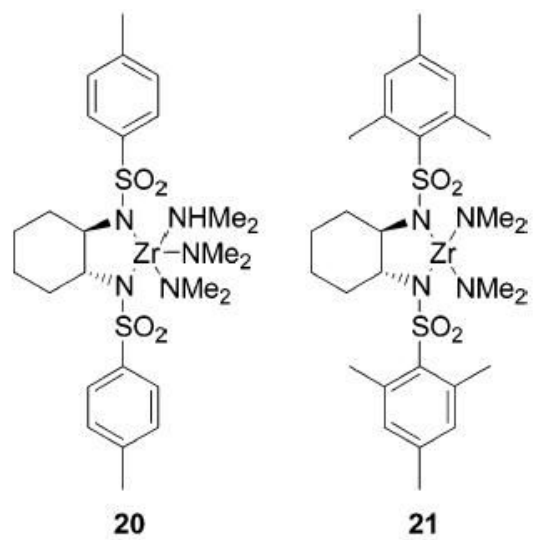

Figure 3.

Zirconium bis(sulfonamido) complexes. 


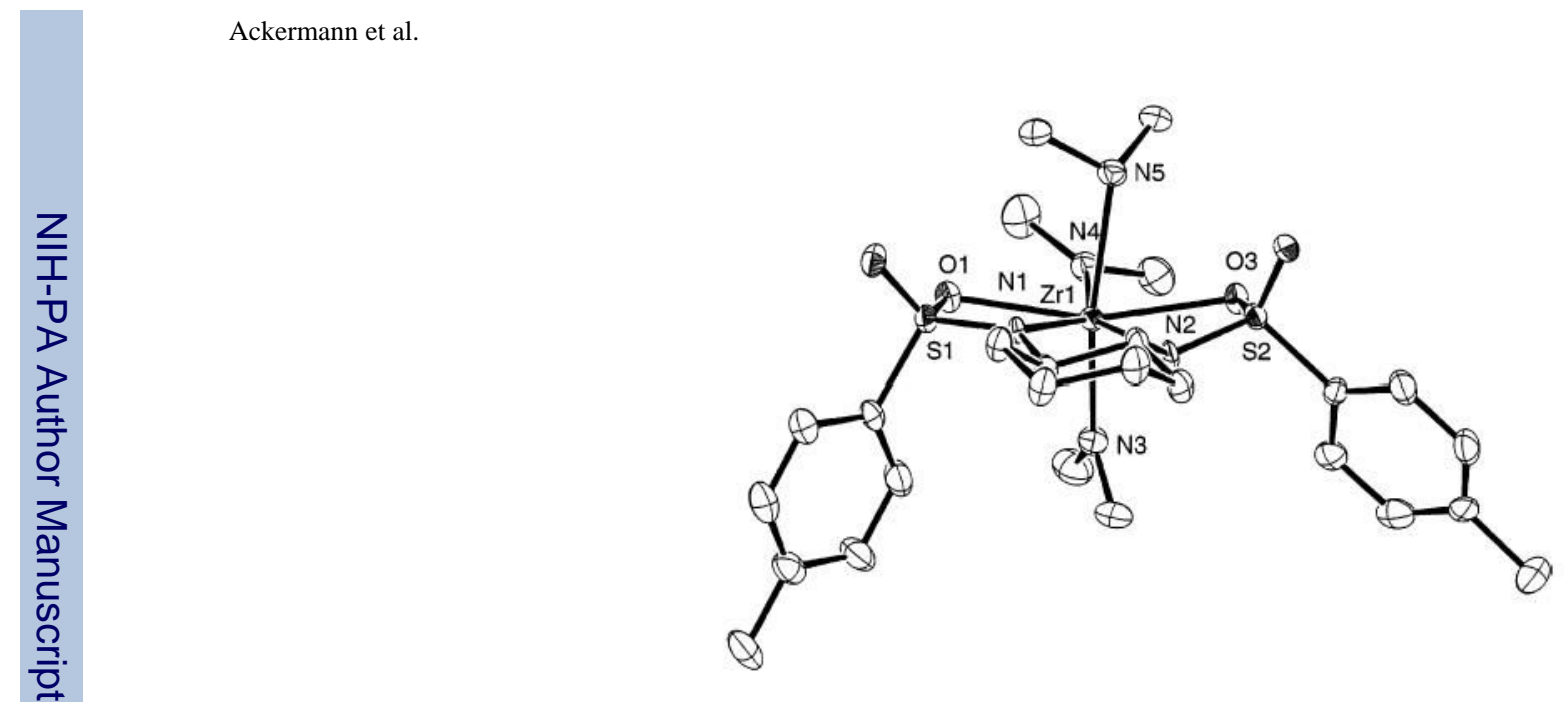

Figure 4.

ORTEP diagram of complex 20. 


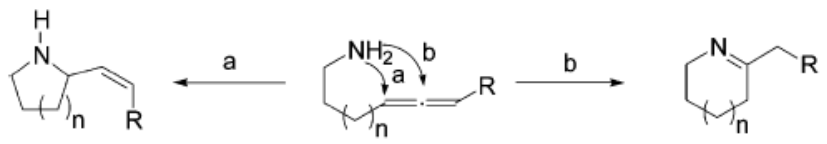

Scheme 1. 


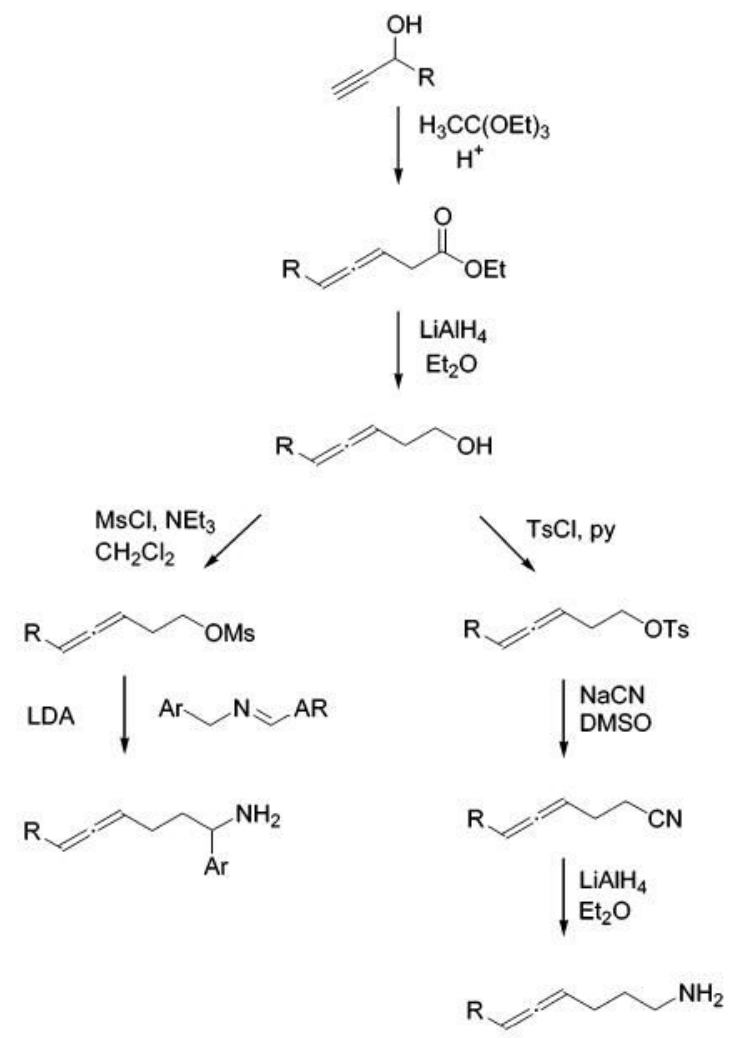

Scheme 2. 


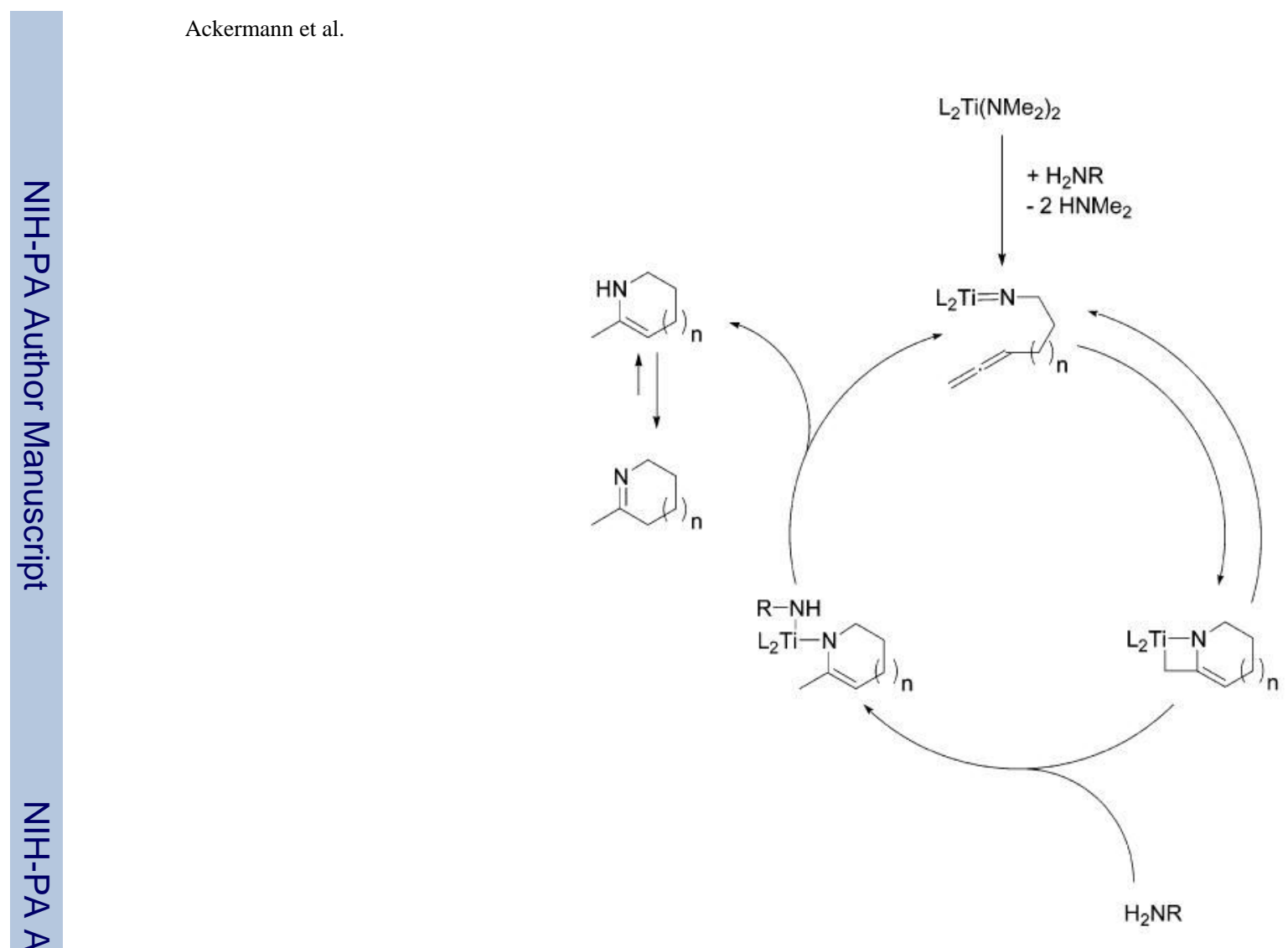

Scheme 3.

$J$ Am Chem Soc. Author manuscript; available in PMC 2006 September 25. 
Hydroamination of Aminoalkyne 4

\section{Table 1}

\begin{tabular}{cccrc}
\hline entry & cat. & $\boldsymbol{T}^{\circ} \mathbf{C}$ & $\boldsymbol{t} \mathbf{h}$ & yield (NMR, \%) \\
\hline 1 & $\mathbf{6}$ & 105 & 16 & - \\
2 & $\mathbf{7}$ & 105 & 2 & - \\
3 & $\mathbf{8}$ & 75 & 3 & 35 \\
4 & $\mathbf{9}^{a}$ & 75 & 16 & 85 \\
5 & $\mathbf{3}$ & 25 & 30 & \\
\hline
\end{tabular}

${ }^{a}$ Prepared in situ from 3 and the corresponding diol. 


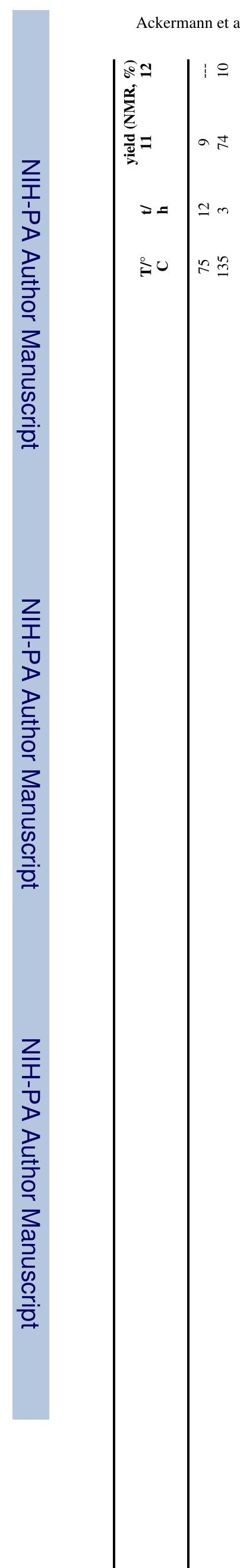




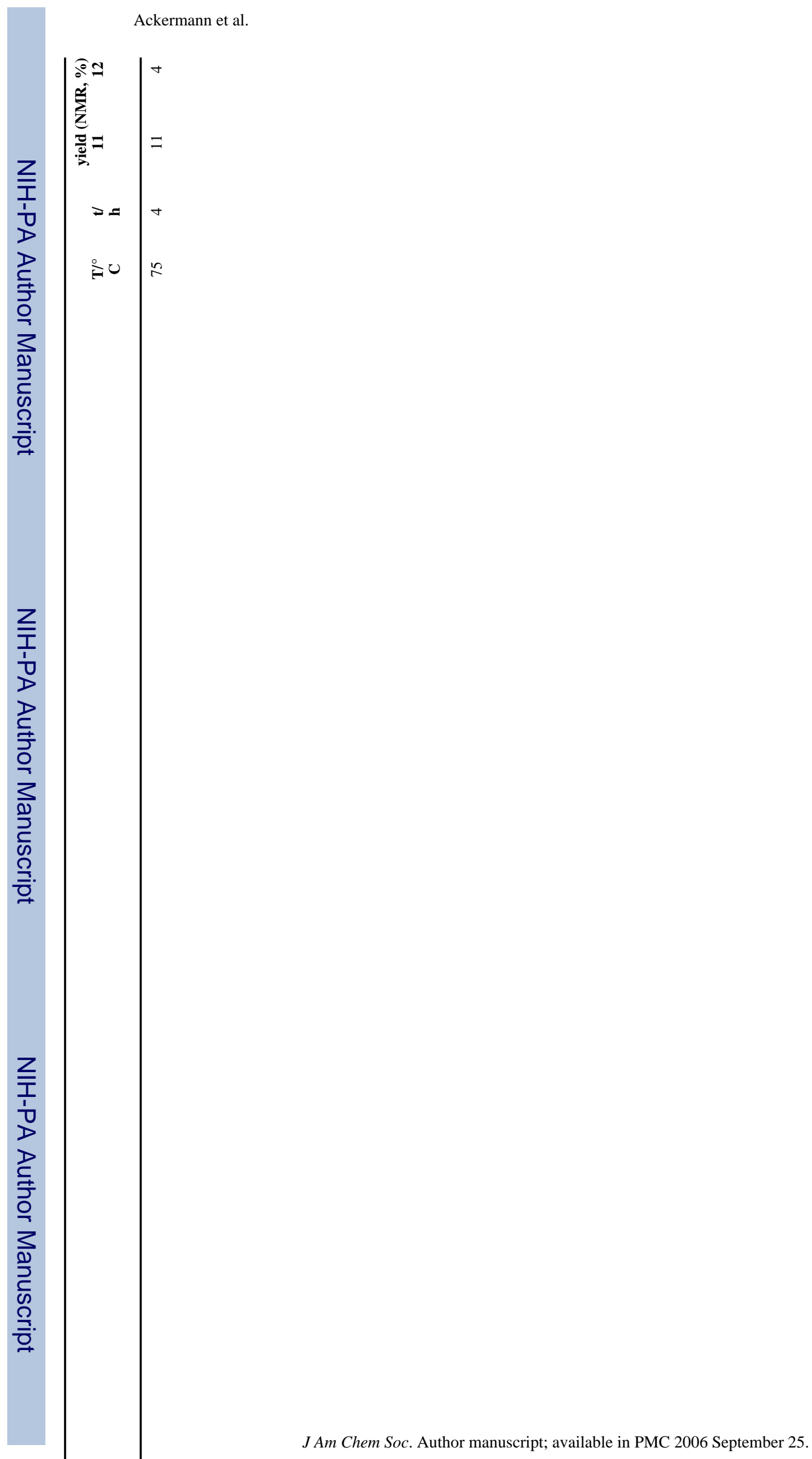




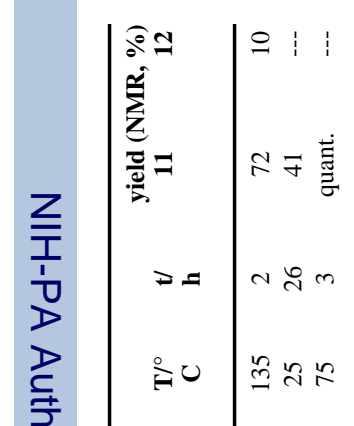




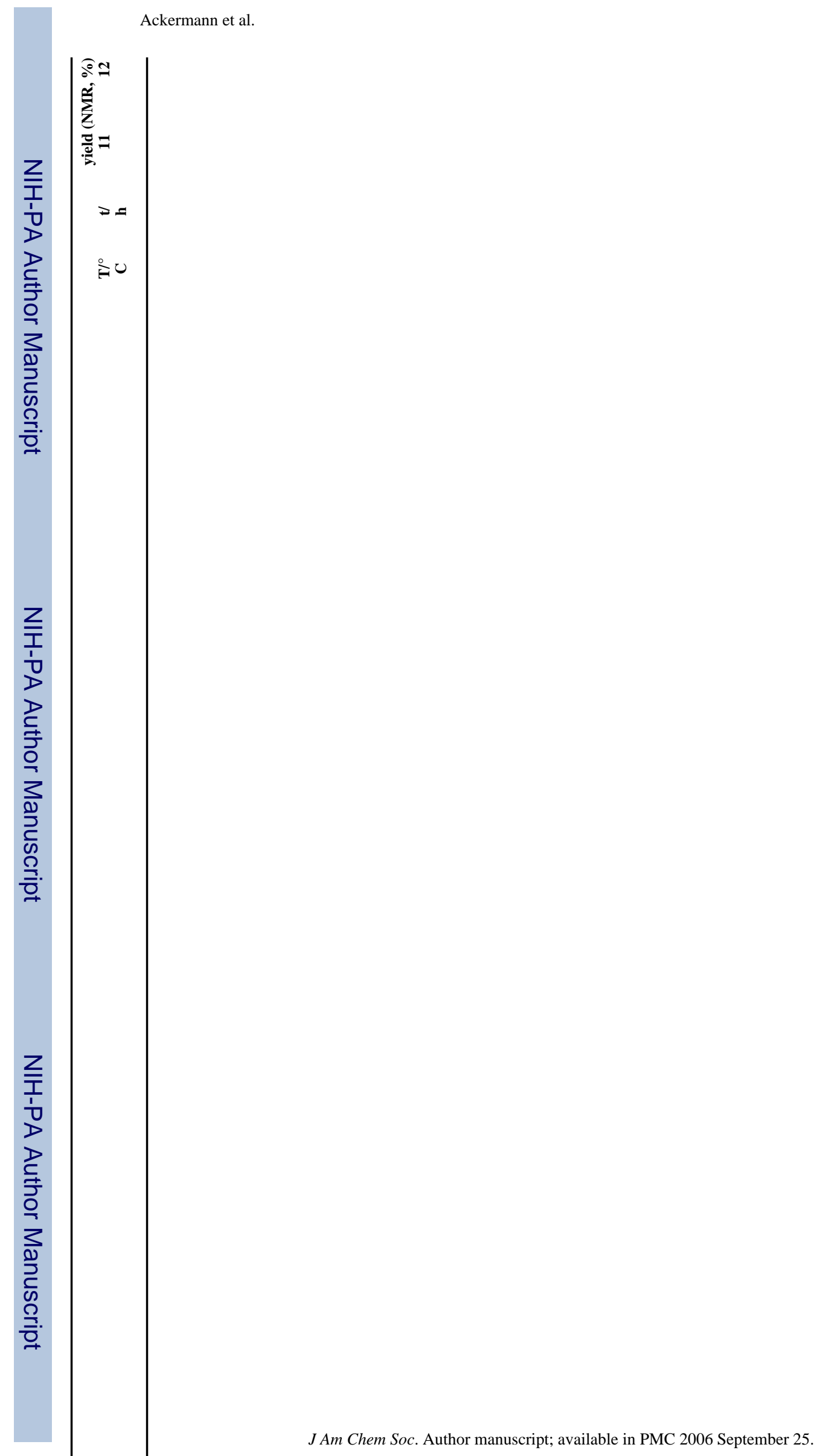




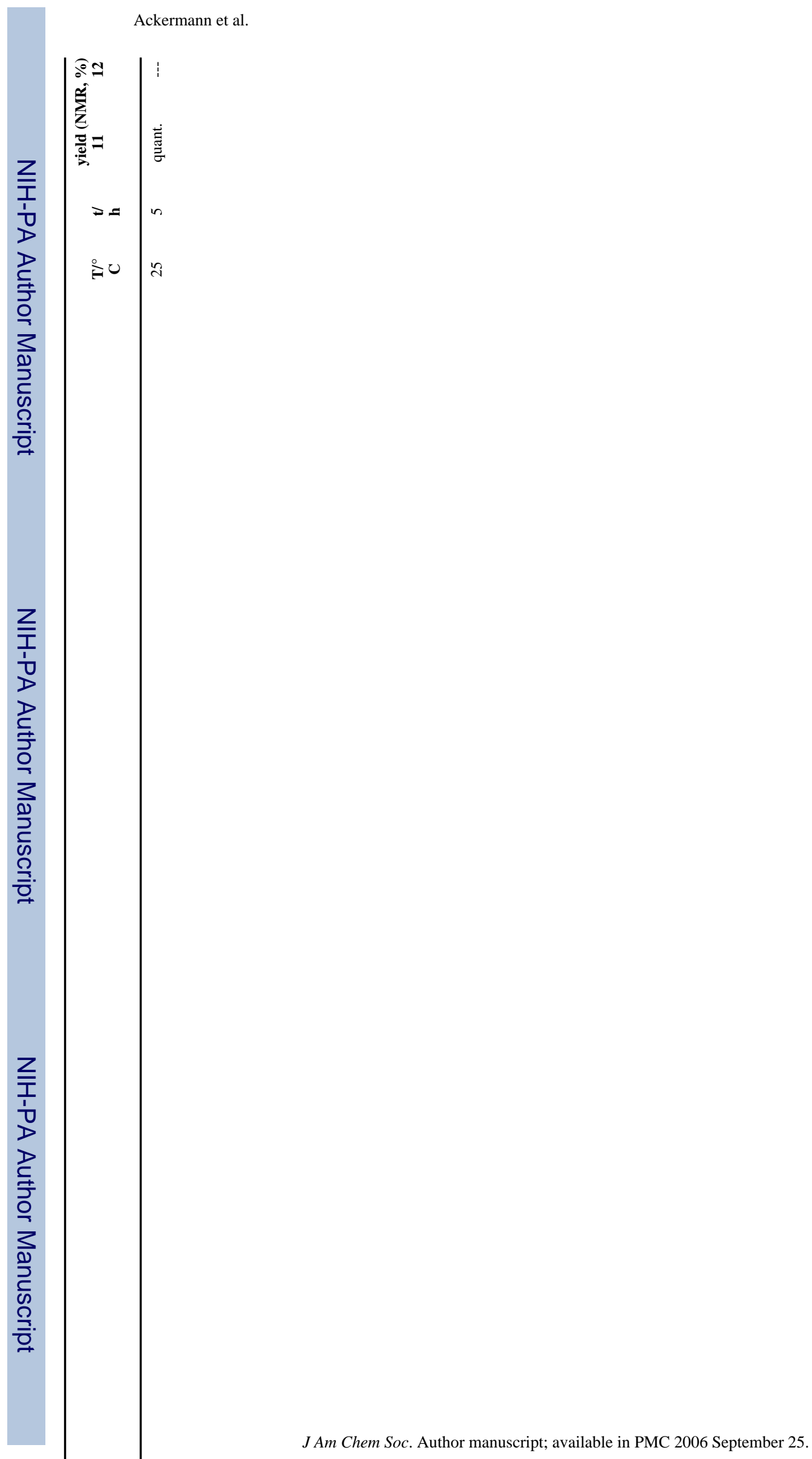




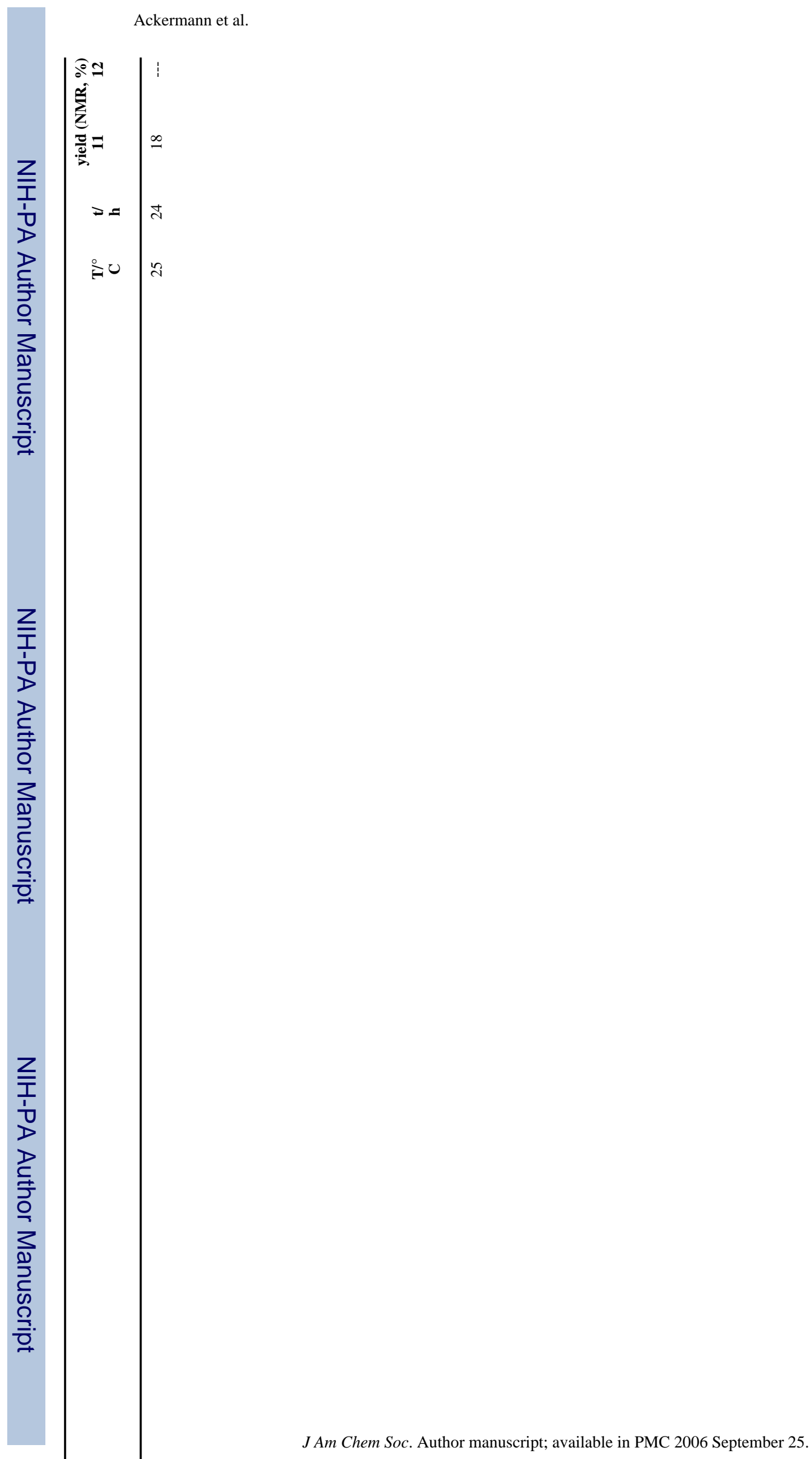

Page 23

Am Chem Soc. Author manuscript; available in PMC 2006 September 25. 


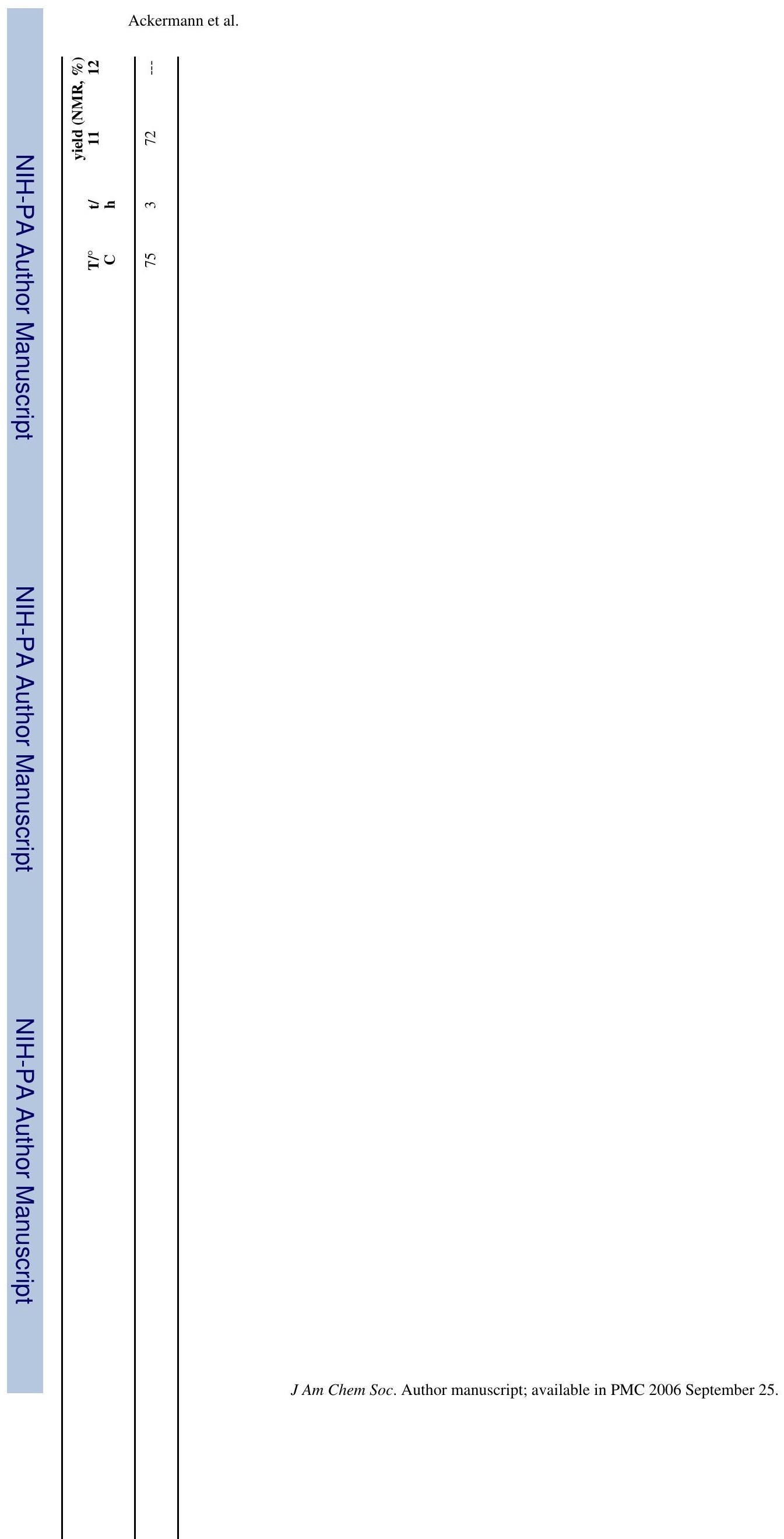

Page 24 


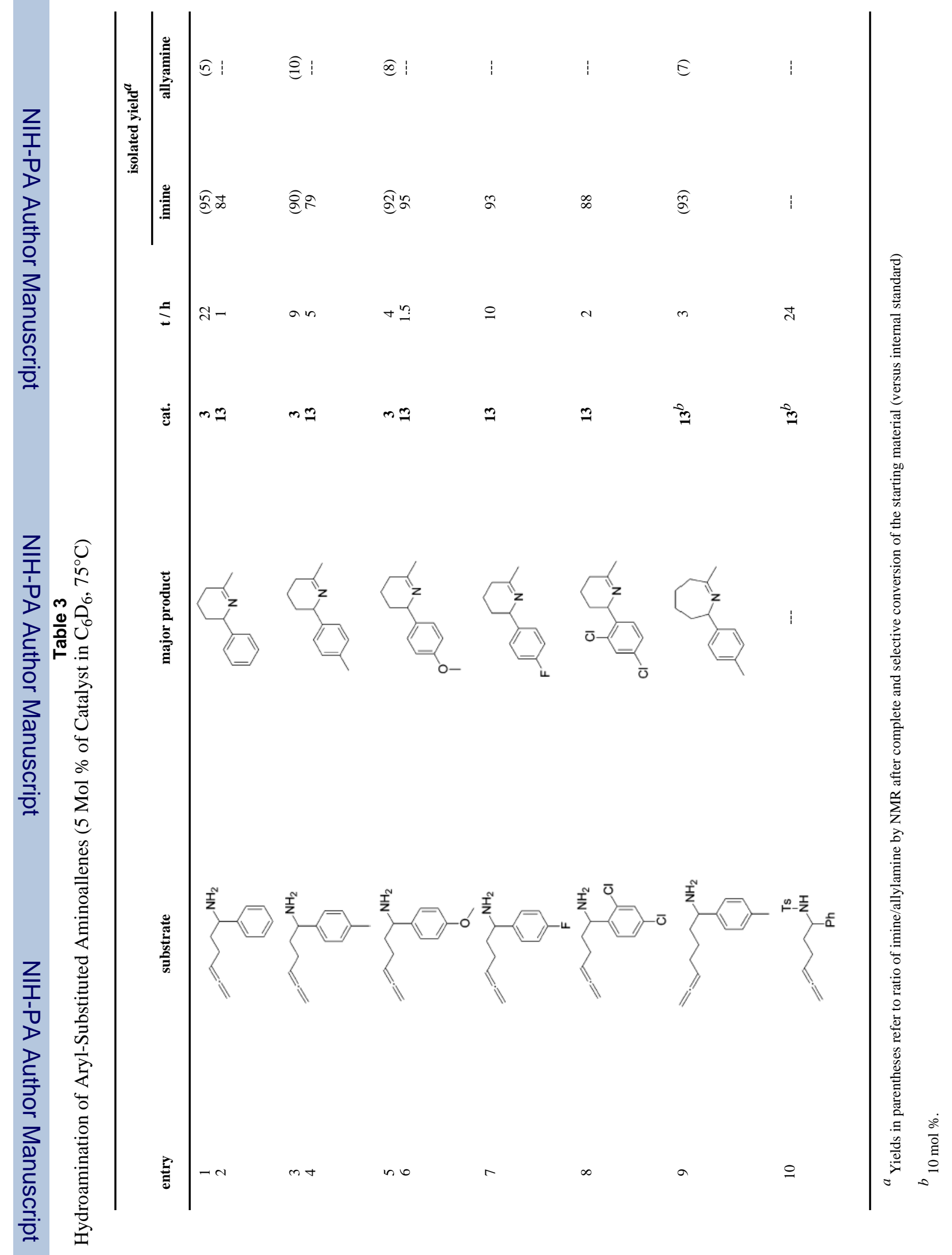

$J$ Am Chem Soc. Author manuscript; available in PMC 2006 September 25. 


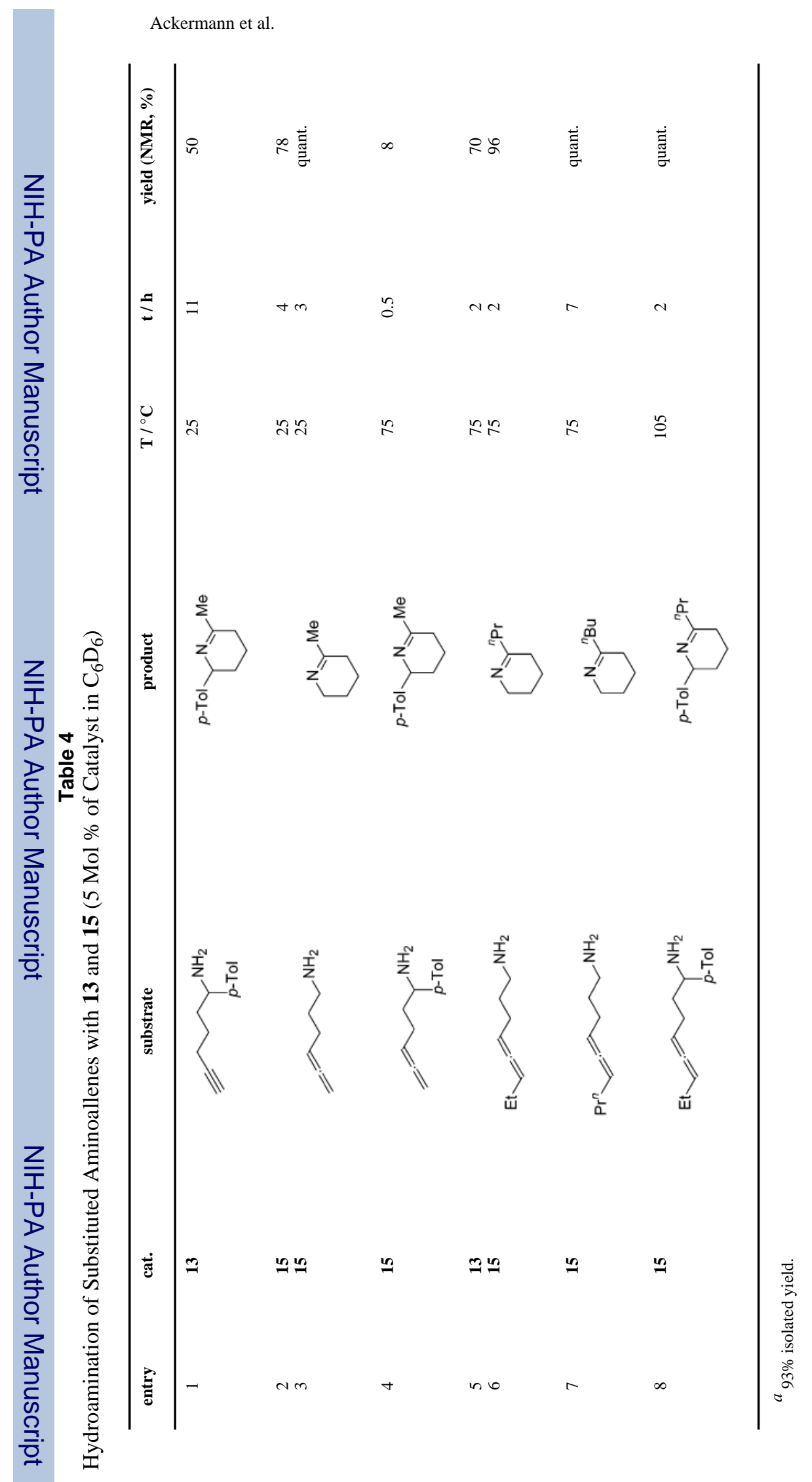

$J$ Am Chem Soc. Author manuscript; available in PMC 2006 September 25. 


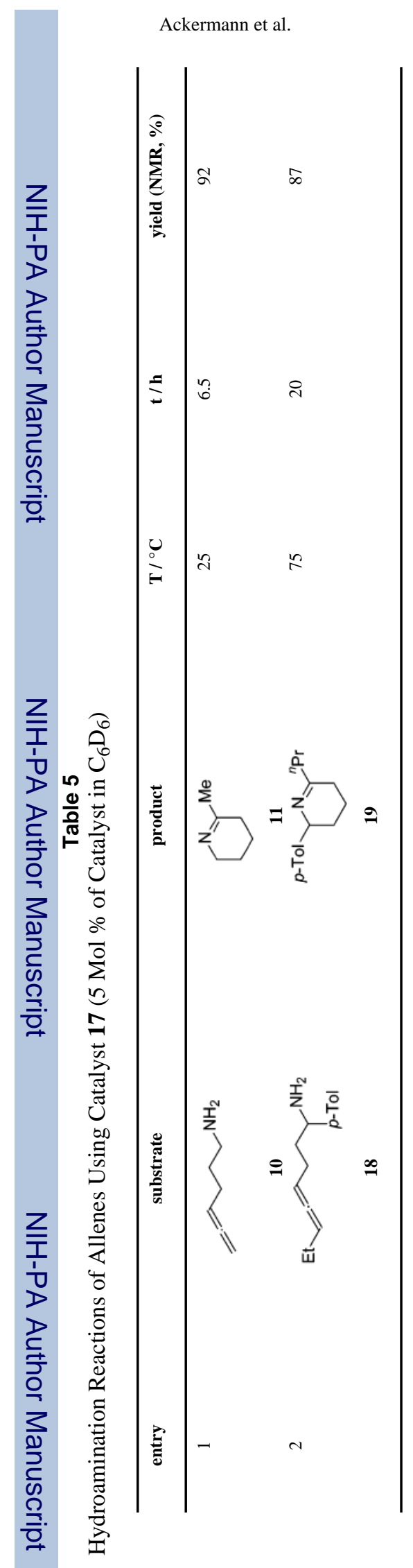

Page 27 
Table 6

Hydroamination of Allene 10 Using Zirconium Complexes (5 Mol \% of Catalyst in $\mathrm{C}_{6} \mathrm{D}_{6}$ )

\begin{tabular}{|c|c|c|c|c|c|}
\hline \multirow[b]{2}{*}{ entry } & \multirow[b]{2}{*}{ cat. } & \multirow[b]{2}{*}{$\mathbf{T} /{ }^{\circ} \mathbf{C}$} & \multirow[b]{2}{*}{$\mathbf{t} / \mathbf{h}$} & \multicolumn{2}{|c|}{ yield (NMR, \%) } \\
\hline & & & & 11 & 12 \\
\hline 1 & $\mathrm{Cp}_{2} \mathrm{ZrMe}_{2}(\mathbf{2 3})$ & 135 & 18 & 16 & 3 \\
\hline 2 & $\mathrm{Cp}_{2} \mathrm{ZrMe}_{2}(\mathbf{2 3}) / \mathrm{B}\left(\mathrm{C}_{6} \mathrm{~F}_{5}\right)_{3}$ & 135 & 18 & 34 & 66 \\
\hline \multirow[t]{2}{*}{3} & $\mathrm{Zr}\left(\mathrm{NMe}_{2}\right)_{4}(\mathbf{2 2})$ & 75 & 24 & 35 & 2 \\
\hline & 20 & 75 & 3 & 10 & - \\
\hline 4 & & 135 & 3 & 84 & 12 \\
\hline 5 & 21 & 75 & 4 & 94 & 6 \\
\hline
\end{tabular}


Table 7

Synthesis of Allylamines Using Zirconium Catalysts 21

\begin{tabular}{|c|c|c|c|c|c|}
\hline entry & product & $\mathbf{T} /{ }^{\circ} \mathbf{C}$ & yield $(\%)^{a}$ & $Z / E$ & regioselectivity \\
\hline 1 & 24 & 75 & $62^{b}$ & $>20 / 1$ & $4 / 1$ \\
\hline 2 & 25 & 75 & 68 & $>20 / 1$ & $7 / 1$ \\
\hline 3 & 26 & $135^{c}$ & 88 & $1.8 / 1$ & $11 / 1$ \\
\hline
\end{tabular}

${ }^{a}$ Isolated as the trifluoroacetamide derivative.

${ }^{b}$ By ${ }^{1}$ H NMR.

${ }^{c} 10 \mathrm{~mol} \% \mathbf{2 1}$. 